\title{
Chaikovsky and the Economics of Art Music in Late Nineteenth-Century Russia
}

Of the many myths surrounding the life and career of Petr Il'ich Chaikovsky, many have been dispelled in recent scholarship. We now have a more sensitive account of his sexuality, allegations of his supposed suicide have been disproven, and criticism has begun to explore his close relationship with the Imperial family. ${ }^{1}$ Yet one myth persists - that of his financial incompetence. The image is still one of Chaikovsky as a spendthrift, unable to manage his income or regulate his outgoings. To an extent, this image is not wholly inaccurate; Chaikovsky often found himself in financial difficulties and depended on friends and benefactors for loans and allowances. Yet as Russia's first professional, conservatory-trained composer, Chaikovsky

Material in this article was first presented at conferences and colloquia at Brandeis University, the University of Cambridge, Kings College, London, the National Portrait Gallery, London, the University of Oxford, and the École des Hautes Études en Sciences Sociales, Paris. I am especially grateful to Rosalind Blakesley, Clare Brandt, Diana Greenwald, Kathryn Grady, Julia Mannherz, Robin Feuer Miller, Jonathan Paine, Melissa Purkiss, Gisèle Sapiro, and William Mills Todd III for their help and advice. I should also like to thank the staff of the Chaikovsky State House Museum, Klin, Russia, for granting me access to the archives there and for permission to draw on that material in this article. I am equally indebted to the anonymous reviewers engaged by The Journal of Musicology for their constructive comments.

${ }^{1}$ See, in particular, Alexander Poznansky, Tchaikovsky: The Quest for the Inner Man (New York: Schirmer, 1991) and Tchaikovsky's Last Days: A Documentary Study (Oxford: Clarendon Press, 1996), Richard Taruskin, "Chaikovsky and the Human: A Centennial Essay," in Defining Russia Musically: Historical and Hermeneutical Essays (Princeton: Princeton University Press, 1997), 239-307, and "Pathetic Symphonist: Chaikovsky, Russia, Sexuality, and the Study of Music," in On Russian Music (Berkeley, Los Angeles and London: University of California Press, 2009), 76-104, and Grigorij Moiseev, "P. I. Čajkovskij und der Großfürst Konstantin Nikolaevič Romanov: Zur Geschichte einer Wechselbeziehung," Mitteilungen der Tschaikowsky-Gesellschaft, 22 (2015): 3-36. 
operated in the rapidly evolving social and economic context of post-emancipation Russia, identifying ways to interact with Russia's musical institutions - its opera houses and theaters, its concert organizations, and publishers - to fashion a career that was as successful financially as it was critically.

Why, then, the resistance to seeing Chaikovsky as one of late Imperial Russia's successful economic agents? One of the principal reasons is related to sources. Even before Chaikovsky had been dead a decade, his vast correspondence Nadezhda von Meck had been mined by critics and biographers. ${ }^{2}$ A complete edition of their letters appeared in the mid-1930s, since when they have formed the basis for any number of publications. ${ }^{3}$ Von Meck's intervention in Chaikovsky's life was, of course, decisive. Between 1877 and 1890, she provided him with a subsidy of 6000 rubles a year, and her largesse allowed him to abandon his teaching position at the Moscow Conservatory and devote himself fully to composition. She paid for works to be performed, underwrote publication costs, and provided him with accommodation, whether on her Ukrainian estates, at her home in Moscow, or during his sojourns in Europe. The fact that Chaikovsky also received an annual pension of 3000 rubles from Alexander III from 1888 only

\footnotetext{
${ }^{2}$ Modest Chaikovsky, Zhizn' Petra Il'icha Chaikovskogo, po dokumentam, khraniashchimsia varkhive pokoinogo kompozitora v Klinu, 3 vols (Moscow and Leipzig: P. Iurgenson, 1900-02), translated into German by Paul Juon as Das Leben Peter Iljitsch Tschaikowskys, 2 vols (Moscow and Leipzig: P. Jurgenson, 1901-3), and into English by Rosa Newmarch as The Life and Letters of Peter Ilich Tchaikovsky (London and New York: John Lane, 1905). ${ }^{3}$ V. A. Zhdanov and N. T. Zhegin (eds), P. I. Chaikovskii: perepiska s. N. F. fon-Mekk, 3 vols (Moscow: Academia, 1934-6). A new edition of the letters is current underway, with three volumes covering the period 1876-1881 having appeared so far. See P. E. Vaidman (ed.), P. I. Chaikovskii-N. F. fon Mekk: Perepiska (Cheliabinsk: Music Production International, 2007- ).
} 
adds to the view of him as an artist seemingly removed from the day-to-day operation of the commercial marketplace.

By contrast, Chaikovsky's extensive correspondence with his publisher, Petr Iurgenson, has been largely neglected as a critical or biographical resource. Running to more than 1200 items in total, it has only recently been published in full. ${ }^{4}$ Evidence for the importance of the relationship between composer and publisher can be found in a letter that Chaikovsky wrote to von Meck in March 1879. Von Meck had discovered that Chaikovsky had approached Iurgenson for money and wrote to express her indignation. Chaikovsky's justification is revealing: "You reproach me for not approaching you directly when I was in need of money. But as a matter of fact, I had no need, as Iurgenson already has my money, money that I have earned and on which I rely."5 "My money," "money that I have earned" - such phrases indicate that although it was von Meck's subsidy that facilitated Chaikovsky's freedom to compose, the true value of his music was to be judged by its ability to appeal to audiences, publishers, theater managers, and concert promoters. For Chaikovsky to speak of "earned" income was to speak of the development of a successful career as a professional composer that was equally important to him as von Meck's patronage. His correspondence with Iurgenson allows us to reconstitute both the nature of that career, as well as the wider operation of a growing market for classical music in late Imperial Russia. Equally, their correspondence attests to a deep friendship in which personal

\footnotetext{
${ }^{4}$ P. E. Vaidman (ed.), P. I. Chaikovskii - P. I. Iurgenson: Perepiska, 1866-1893, 2 vols (Moscow: P. I. Iurgenson, 2011-13). The earlier, Soviet-era edition of their correspondence was heavily censored. See P. I. Chaikovskii, Perepiska s P. I. Iurgensonom, eds. V. A. Zhdanov and N. T. Zhegin, 2 vols (Moscow: Gosudarstvennoe izdatel'stvo, 1938-52).

${ }^{5}$ Letter of 13, 19, and $22 \mathrm{March} / 25$ and 13 March, 3 April, in Vaidman (ed.), P. I. Chaikovskii - N. F. fon Mekk: Perepiska, III, 93.
} 
and professional interests were intimately and advantageously entwined. Indeed, so close was their relationship that when, in August 1880, the German conductor Benjamin Bilse asked Chaikovsky for copies of works to perform in Berlin, the composer urged his publisher to dispatch what he revealingly described as "our music". 6

If their correspondence sheds light on Iurgenson's role in Chaikovsky's career, it also illuminates the ways in which the "culture business" came into being in post-emancipation Russia. Unlike other members of the merchant community, such as Savva Mamontov, Pavel and Sergei Tret'iakov, or Mitrofan Beliaev, who made their money in industry and then used their wealth to support cultural activity in an ostensibly disinterested manner, ${ }^{7}$ Iurgenson's activities as a publisher and his close involvement in institutions such as the Russian Musical Society meant that he occupies a near unique place at the heart of Russian artistic life itself. As well as publishing almost all of Chaikovsky's compositions (and advising the composer how to deal with the disadvantageous arrangement he had naively made with Vasilii Bessel' in 1872, and which covered works such as the opera, The Oprichnik, and the Second Symphony, as well as a number of songs and piano pieces), Iurgenson administered Chaikovsky's relationship with the Imperial Exchequer, the Imperial Theaters Directorate, the Russian Musical Society, operatic entrepreneurs around the Russian Empire, and - as Chaikovsky’s reputation spread internationally - opera houses, concert promoters, and publishers abroad. Iurgenson was more than just Chaikovsky's publisher; he was his banker, accountant, and agent all in one.

\footnotetext{
${ }^{6}$ Letter of 3/15 August 1880, in Vaidman (ed.), P. I. Chaikovskii-P. I. Iurgenson: Perepiska, I, 229.

${ }^{7}$ Beverly Whitney Kean, French Painters, Russian Collectors: The Merchant Patrons of Modern Art in PreRevolutionary Russia, revised edition (London: Hodder \& Stoughton, 1994), and Olga Haldey, Mamontov's Private Opera: The Search for Modernism in Russian Theatre (Bloomington: Indiana University Press, 2010).
} 
In proposing a more nuanced and systematic account of Chaikovsky's economic agency than has been attempted hitherto, this article contributes to a growing body of work on the institutional structures that shaped the Russian arts in the nineteenth century. ${ }^{8}$ By revisiting the professionalization of Russian musical life in the second half of the nineteenth century from a new perspective, this article seeks to complement the study of such familiar topics as nationalism, cosmopolitanism, and the establishment of Western-style conservatory training, with an emphasis on the operation of networks, the circulation of culture, and the impact of new technologies. ${ }^{9}$ The relationship between Iurgenson and Chaikovsky represents, therefore, not just a fortuitous personal encounter that led to an intimate lifelong friendship, but also a productive

\footnotetext{
${ }^{8}$ See, for instance, Andrei Shabanov, Peredvizhniki mezhdu kommercheskim tovarishchestvom i khudozhestvennym dvizheniem (St. Petersburg: Izdatel'stvo Evropeiskogo universiteta v Sankt-Peterburge, 2015); Anne Swartz, Piano Makers in Russia in the Nineteenth Century (Bethlehem: Lehigh University Press, 2014); Lynn M. Sargeant, Harmony and Discord: Music and the Transformation of Russian Cultural Life (New York: Oxford University Press, 2011), Murray Frame, School of Citizens: Theatre and Civil Society in Imperial Russia (New Haven and London: Yale University Press, 2006), and Jonathan Paine, Buying the Story: Transaction and Narrative Value in Balzac, Dostoevsky, and Zola (Cambridge, MA: Harvard University Press, forthcoming). More broadly, see Sergei Antonov, Bankrupts and Usurers of Imperial Russia: Debt, Property, and the Law in the Age of Dostoevsky and Tolstoy (Cambridge, MA: Harvard University Press, 2016), Ekaterina Pravilova, A Public Empire: Property and the Quest for the Common Good in Imperial Russia (Princeton: Princeton University Press, 2014), and William Craft Brumfield, Boris V. Anan'ich, and Yuri A. Petrov (eds), Commerce in Russian Urban Culture, 1861-1914 (Washington, DC: Woodrow Wilson Center Press; Baltimore and London: Johns Hopkins University Press, 2001). ${ }^{9}$ See, above all, Robert C. Ridenour, Nationalism, Modernism, and Personal Rivalry in Nineteenth-Century Russian Music (Ann Arbor: UMI Research Press, 1981), Marina Frolova-Walker, Russian Musical Nationalism from Glinka to Stalin (New Haven and London: Yale University Press, 2007), and Rutger Helmers, Not Russian Enough?:
} Nationalism and Cosmopolitanism in Nineteenth-Century Russian Opera (Rochester, NY: University of Rochester Press, 2014). 
interaction the composer's creative gifts and the possibilities offered by his publisher's astute exploitation of technological innovation (all set, of course, against the backdrop of the foundation of the Russian Musical Society and the establishment of the St. Petersburg and Moscow Conservatories). ${ }^{10}$ It should be noted at the outset that this article does not constitute a piece of economic history as such, nor does it use historical, statistical, or social sciences methodologies to explore the particular case of Chaikovsky. Rather, it draws on developments in these fields to shed light on some of the surviving raw data about Chaikovsky's financial relationship with key cultural institutions in late Imperial Russia. In particular, it analyzes the relationship between Chaikovsky, Iurgenson, and the operation of Russia's musical "marketplace" at the level of genre, examining the interaction between financial considerations on the one hand, and Chaikovsky's decision to work in particular musical forms on the other. It is by examining the interrelationship between Russia’s nascent musical institutions, Chaikovsky's particular collaboration with his publisher, and the relative status of different musical genres, that is becomes possible to establish the nature of Russia's musical "art world" in the second half of the nineteenth century. Derived from the work of Howard Becker, and nuanced with reference to the work of Pierre Bourdieu, the notion of "art world" offers a conceptual space which can potentially resist reductively deterministic accounts of cultural production on the one hand, and the over-determined emphasis on autonomous genius on the other, proposing instead a

\footnotetext{
${ }^{10}$ Boris Vol'man's Russkie notnye izdaniia XIX-nachala XX veka (Leningrad: Muzyka, 1970) remains a locus classicus when it comes to histories of Russian music publishing. See too S. V. Belov, Muzykal'noe izdatel'stvo P. I. Iurgenson (St. Petersburg: Izdatel'sto Rossiiskoi national'noi biblioteki, 2001). In the literary field, see Jeffrey Brooks, When Russia Learned to Read: Literacy and Popular Literature, 1861-1917 (Princeton, NJ: Princeton University Press, 1985), and A. I. Reitblat, Ot Bovy k Bal'montu: ocherki po istorii chteniia v Rossii vo vtoroi polovine XIX veka (Moscow: Izdatel'stvo MPI, 1991).
} 
sociologically-inflected reading of culture in which agency resides precisely at the point where the individual creative artist interacts with the structures that facilitate both the production and consumption of art works. ${ }^{11}$

\section{How much did Chaikovsky earn?}

In the early years of their friendship, Chaikovsky regularly turned to Iurgenson for ready cash and Iurgenson, intuiting that Chaikovsky might prove to be a wise investment, invariably obliged. Even as Chaikovsky settled into his new life as a professor at the Moscow Conservatory, he continued to rely on Iurgenson for financial aid. In the summer of 1871, for instance, he asked for 50 rubles, "which I need just as a fish needs water." "In fact," he went one, "I am done for if you don't send the money, and as soon as you can, since something particular has come up, about which I shall tell you when I see you." ${ }^{12}$ The following year saw him begging for help once again: "My soul! I implore you to give me another 50 silver rubles, and if that's not possible, then 25 against the remaining 100." ${ }^{\prime 13}$ Later on, he wrote in more and more anxious vein: “Petrusha! Send me, for heaven's sake, anything at all, i.e. 5 or 10 silver rubles." Similarly, in

\footnotetext{
${ }^{11}$ Howard Becker, Art Worlds (Berkeley: University of California Press, 1982), Pierre Bourdieu, The Rules of Art: Genesis and Structure of the Literary Field, trans. Susan Emanuel (Cambridge: Polity Press, 1996), and The Field of Cultural Production: Essays on Art and Literature, ed. Randal Johnson (Cambridge: Polity Press, 1993). See too Bruno Latour, Reassembling the Social: An Introduction to Actor-Network-Theory (Oxford and New York: Oxford University Press, 2005).

${ }^{12}$ Letter of 15/27 August 1871, in Vaidman (ed.), P. I. Chaikovskii - P. I. Iurgenson: Perepiska, I, 15.

${ }^{13}$ Undated latter [1872], in ibid., I, 18.
} 
the spring of 1873, he turned to Iurgenson for assistance: "Send me, if you can, 15 silver rubles, which will save me and my household from inevitable disaster."14

This pattern would never entirely disappear, but in most cases, Chaikovsky's entreaties were based on the fact that he was merely asking for a share of money he had already earned, or for an advance against future sales and performances. Writing in May 1873, for instance, he announced his intention of collecting his most recent royalties:

On Wednesday I shall come to collect my capital from you. Our accounts are as follows: you told me that I should receive from you 335 rubles, including 100 for The Snow Maiden. I think that in the light of the less than brilliant success of this piece I cannot take such a huge sum from you, so will be happy with 50 . So, you owe me 285 rubles and not 335. Moreover, I borrowed from you the day before yesterday 50; which leaves 235; but I ask you to send with my messenger another 25 silver rubles, which leaves the sum of 210 silver rubles. ${ }^{15}$

Iurgenson was also able to facilitate more substantial advances, not least in the summer of 1880 , when Chaikovsky confessed to being in debt to the sum of 4000 rubles, including 1000 rubles owed to his brother-in-law, Lev Davydov, 500 rubles to Dmitry Shenshin, a retired major general, 500 rubles to a moneylender at Kamenka (his brother-in-law's estate), and 600 rubles to his manservant, Aleksei Sofronov, as well as a number of sundry smaller debts. ${ }^{16}$ Iurgenson

\footnotetext{
${ }^{14}$ Ibid.

${ }^{15}$ Undated letter [between 17/29 May and 21 May/3 June 1873], in ibid., I, 19.

${ }^{16}$ Letter of 3/15 July 1880, in ibid., I, 219-22.
} 
brokered an agreement with Sergei Tret'iakov, who anonymously provided 2000 rubles, whilst Iurgenson waived the 1000 rubles that Chaikovsky owed him and suggested ways of dealing with the remaining $1000 .{ }^{17}$ Chaikovsky's decision to approach Iurgenson for a substantial loan is noteworthy, as he could easily have turned to von Meck instead:

\begin{abstract}
All it would take, of course, is to write to Mme von Meck herself, and she, without thinking about it for a minute, would do it. But I cannot, cannot, as there is a limit to everything. She would give me this money without expecting repayment - she never does anything any other way, but I do not want to abuse her extreme kindness and delicacy for anything in the world. ${ }^{18}$
\end{abstract}

Chaikovsky's refusal to approach his benefactor is presented here as a form of tact, but it can also be interpreted as evidence of his financial self-confidence. Aware that he could clear a substantial debt through income derived from performances of his works, he chose to consolidate a series of individual debts into a single liability, in which artistic value is translated into economic capital.

Chaikovsky may often have been in need of money, yet he had a firm grasp of the overall state of his finances, as suggested by a letter written to Iurgenson on 18 January 1889:

I have the reputation of being someone incapable of coping with the state of his finances, but in essence it's not at all like that. I almost always know how much money I have, i.e.

\footnotetext{
${ }^{17}$ Letter of $15 / 27$ July 1880 , in ibid., I, 222-3.

${ }^{18}$ Letter of 3/15 July 1880, in ibid., I, 221.
} 
how much I owe and how much I am owed, i.e. I can almost always remember what I am due from the theaters, how much Iurgenson owes me, or I owe him, how much of my reserves I have tapped into, etc. Usually, when I received my account from you, I find it much as I had expected, and if there's any surprise, it's usually in my favor. ${ }^{19}$

The main way in which Chaikovsky kept abreast of his financial situation was through the regular accounts that Iurgenson prepared for him. Thirteen such documents survive, dating from between September 1879 and July $1893 .{ }^{20}$ Relating to the period when Chaikovsky had given up his teaching position at the Moscow Conservatory, they shed light on how he negotiated the demands of a career as a professional composer. Each account contains columns for both income and expenditure: the former contains the fees that Iurgenson would pay for individual works, box office income for performances of stage works and orchestral compositions, and his Imperial pension; the latter includes regular cash advances that Chaikovsky would draw, especially when traveling abroad, payments to a large number of family members and other dependents, and household expenses incurred by his manservant, Aleksei.

Analysis of these accounts is complicated by the fact that there are a number of gaps in the record, and that the particular periods covered vary in length from two and a half months to a whole year. ${ }^{21}$ They also omit von Meck’s subsidy (plus other sums disbursed by her, whether

\footnotetext{
${ }^{19}$ Letter of 18/30 January 1889, in ibid., II, 177.

${ }^{20}$ Chaikovsky State House Museum, Klin, $\mathrm{a}^{15}$ 45/50. These tables have never been published, although a number of them are cited in the most recent edition of Chaikovsky's correspondence with Iurgenson.

${ }^{21}$ Iurgenson's letters contain references to accounts that do not seem to have survived. See, for instance, letters of 3/15 October 1879, 8/20 August 1880, 28 July/9 August 1883, 1/13 August 1883, and 9/21 January 1884, in Vaidman (ed.), P. I. Chaikovskii-P. I. Iurgenson: Perepiska, I, 169, 229, 452, 454, and 472.
} 
directly or indirectly), as well as fees paid directly to Chaikovsky by other agents. Nonetheless, they do provide the single most coherent overview of his finances and suggest that between 1879 and 1886, his income hovered around 2000-4000 rubles a year. Between 1886 and 1889, this figure rose to between 6000 and 12000 rubles a year, rising again to more than 16000 rubles in 1890. Thereafter, his income fell to just under 2000 rubles by the middle of 1891 and around 5000 rubles by the summer of 1893. Over this thirteen-year period, Chaikovsky's outgoings broadly corresponded to his income and he could often be confident of being in credit to his publisher, although there are also periods when his outgoings significantly outstrip his income.

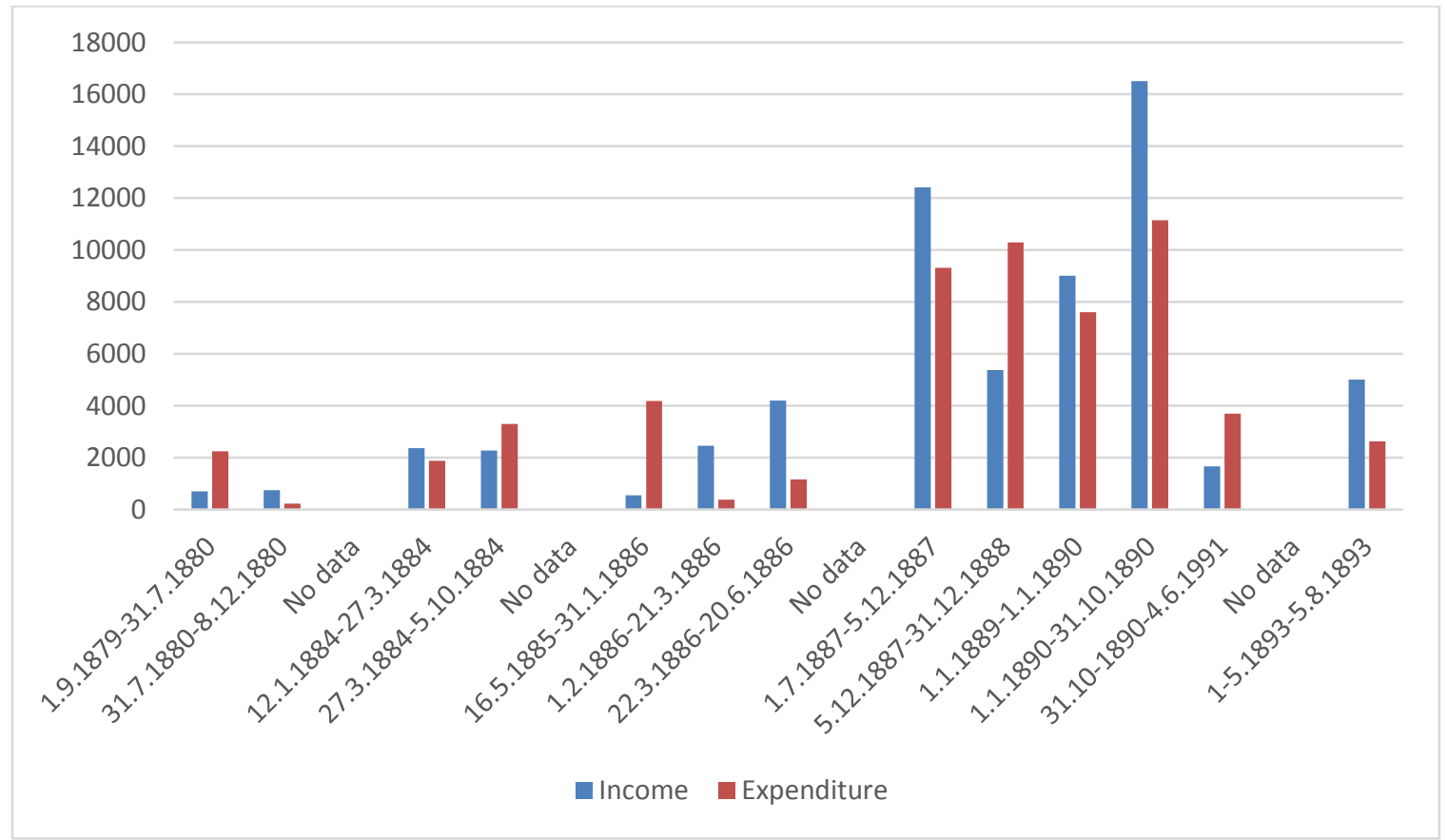

FIGURE 1: Chaikovsky's accounts with Iurgenson, 1879-1893. Source: Chaikovsky State House Museum, Klin.

So how substantial were such figures, relative to living standards in the Russian Empire? According to an article published in 1876, a professional writer required an annual income of 
around 2000 rubles a year in order to be able to support a wife and child (additional expenses such as a foreign vacation on health grounds were unthinkable on such a sum). ${ }^{22}$ By comparison, when Chaikovsky joined the Moscow Conservatory in September 1866, his initial salary was just 600 rubles a year, rising to 1500 rubles in 1871. By 1872, he was earning 2300 rubles (plus a small additional salary from his work as a critic for the Moscow News). ${ }^{23}$ Yet, as he wrote to his father that year, Chaikovsky still did not feel able to marry: “As far as marriage is concerned, I can tell you that I myself often think of burdening myself with a wife, only I am afraid of repenting afterwards. Although I am earning reasonably well (around 3000 rubles a year), I am nonetheless always in debt and in difficult situations. This is acceptable on one's own, but how would it be with a wife and small children?"24 Then, writing to Anton Arensky in the summer of 1891 (at a time when Arensky was considering whether to give up his post as professor of composition at the Moscow Conservatory and take up the directorship of the Tbilisi branch of the Russian Musical Society instead), Chaikovsky offered this summary both of his own career, and of the predicament of his fellow Russian musicians:

You cannot imagine, dear Anton Stepanovich, how much I suffer when I think of how people such as you, Rimsky-Korsakov, and Liadov must endure and torment yourselves with teaching. But what can one do? It seems to me that you should endure a couple more years and try to work hard, and heaven knows, perhaps imperceptibly, little by little, you

\footnotetext{
${ }^{22}$ S. S. Shashkov, "Literaturnyi trud v Rossii (istoricheskii ocherk)," Delo, 8 (1876): 1-48, at 43.

${ }^{23}$ Chaikovsky, Zhizn' Petra Il'icha Chaikovskogo, I, 201, 372, and 392.

${ }^{24}$ Letter of 22 November/4 December 1872, in Petr Il'ich Chaikovskii, Polnoe sobranie sochinenii: literaturnye proizvedeniia i perepiska (Moscow: Gosudarstvennoe muzykal'noe izdatel'stvo, 1953-81), V (1959), 290.
} 
will manage to live by composition alone. I am the proof that that this should be possible.

I now earn sufficient to support a large family. ${ }^{25}$

Although Chaikovsky often felt that his finances were inadequate they were clearly more than ample by the standards of the day. The data contained in his accounts illustrate that by the end of the nineteenth century a career as a full-time composer was potentially a viable one, even for an artist as profligate as Chaikovsky could be.

A more dynamic account of Chaikovsky's income can be gained by examining the fees which he received for individual works (table 1, where the dates refer either to those noted in Chaikovsky's accounts, or to references in his correspondence with Iurgenson).

\begin{tabular}{|l|l|l|}
\hline WORK & DATE & FEE \\
\hline Snow Maiden, op. 12 & May/June 1873 & 100 rubles \\
\hline Six Pieces for Piano, op. 19 & October/November 1873 & 100 rubles \\
\hline Piano Sonata, op. 37 & 29 July 1878 & 50 rubles \\
\hline Six Romances, op. 38 & 29 July 1878 & 150 rubles \\
\hline Twelve Pieces, op. 40 & 29 July 1878 & 300 rubles \\
\hline Children's Album, op. 39 & 29 July 1878 & 240 rubles \\
\hline Liturgy of St. John Chrysostom, op. 41 & 29 July 1878 & 100 rubles \\
\hline Souvenir d'un lieu cher, op. 42 & 29 July 1878 & 75 rubles \\
\hline Suite No. 1, op. 43 & 27 December 1879 & 100 rubles \\
\hline
\end{tabular}

${ }^{25}$ Letter of 7/19 July 1891, in ibid., XVI-A (1976), 168. 


\begin{tabular}{|c|c|c|}
\hline Piano Concerto No. 2, op. 44 & 31 July 1880 & 500 rubles \\
\hline Capriccio Italien, op. 45 & 31 July 1880 & 100 rubles \\
\hline Six Duets, op. 46 & 30 October 1880 & 350 rubles \\
\hline Seven Romances, op. 47 & 30 October 1880 & 300 rubles \\
\hline Serenade for Strings, op. 48 & 30 October 1880 & 100 rubles \\
\hline Piano Trio, op. 50 & 7/8 March 1882 & 500 rubles \\
\hline Mazepa, no op. & 28 July 1883 & 2400 rubles \\
\hline Moscow and Coronation March & 1 August 1883 & 500 rubles \\
\hline Suite No. 2, op. 53 & 5 November 1883 & 500 rubles \\
\hline Sixteen Children's Songs, op. 54 & 13 November 1883 & 400 rubles \\
\hline Suite No. 3, op. 55 & 4 October 1884 & 300 rubles \\
\hline Concert Fantasia, op. 56 & 4 October 1884 & 200 rubles \\
\hline Caprice Impromptu, no op. & 22 March 1886 & 100 rubles \\
\hline Dumka, op. 59 & 22 March 1886 & 100 rubles \\
\hline Twelve Romances, op. 60 & 3 April 1886 & 1200 rubles \\
\hline The Enchantress & 18 May 1887 & 3000 rubles \\
\hline Mozartiana, op. 61. & 26 October 1887 & 500 rubles \\
\hline Pezzo capriccioso, op. 62 & 26 October 1887 & 100 rubles \\
\hline Six Romances, op. 63 & 27 October 1888 & 600 rubles \\
\hline Symphony No. 5, op. 64 & 30 September 1888 & 500 rubles \\
\hline Six Romances, op. 65 & 17/18 October 1888 & 600 rubles \\
\hline Sleeping Beauty, op. 66 & 30 November 1889 & 1000 rubles \\
\hline Hamlet, op. 67 & 31 January 1890 & 500 rubles \\
\hline
\end{tabular}




\begin{tabular}{|l|l|l|}
\hline Queen of Spades, op. 68 & 31 October 1890 & 5000 rubles \\
\hline Souvenir de Florence, op. 70 & 28 January 1892 & 400 rubles \\
\hline Iolanta, op. 69 and Nutcracker, op. 71 & 14 March 1892 & 5000 rubles \\
\hline Eighteen Pieces for Piano, op. 72 & 21 May 1893 & 2700 rubles \\
\hline Six Romances, op. 73 & 21 May 1893 & 900 rubles \\
\hline
\end{tabular}

FIGURE 2: Fees for Chaikovsky's works. Sources: Chaikovksy State House Museum, Klin; P. E. Vaidman (ed.), P. I. Chaikovskii - P. I. Iurgenson: Perepiska, 1866-1893, 2 vols (Moscow: P. I. Iurgenson, 2011-13); and Modest Chaikovsky, Zhizn' Petra Il'icha Chaikovskogo, po dokumentam, khraniashchimsia $v$ arkhive pokoinogo kompozitora $v$ Klinu, 3 vols (Moscow and Leipzig: P. Iurgenson, 1900-02).

Unsurprisingly, there is a marked increase in the fees that Chaikovsky could command as his reputation grew. In most cases, these were proposed by Iurgenson, who struck a delicate balance between supporting Chaikovsky's creativity on the one hand, and defending his own business interests on the other. Chaikovsky was generally coy when it came to negotiating terms, perhaps conscious that he owed his freedom to compose as much to Iurgenson as he did to von Meck. In February 1882, for instance, Iurgenson asked what kind of fee he required for his recent works. Chaikovsky temporized: "Neither for Bortniansky, nor for the All-Night Vigil can I name a sum. I don't want too much, neither do I want too little. If you like, we can discuss it when we meet, and for now, just add it to my account, only help a drowning man in an ocean of expenses..."26 Elsewhere, he even protested against what he saw as Iurgenson's inclination to be more generous

\footnotetext{
${ }^{26}$ Letter of 18 February/2 March 1882, in Vaidman (ed.), P. I. Chaikovskii - P. I. Iurgenson: Perepiska, I, 351.
} 
than might reasonably be expected (at least in crude, commercial terms). Writing of the Piano Trio, Chaikovsky proclaimed himself to be bashful about the financial value that Iurgenson had put on the work:

So far all the fees which you have offered me for my modest works have always seemed to me excessive, but out of extravagance and disarray I have always had the criminal weakness to agree to them. So, for instance, now, if I am to speak to you as a friend, and not as the retailer of my works, I should tell you that the sum of 500 rubles that you propose for the Trio is excessively large. However, I am glad you have proposed it, since, having found myself in a difficult situation, I crave income. Perhaps I am abusing your Iurgensonian magnanimity? ${ }^{27}$

In other cases, however, Chaikovsky proved to be more confident about asserting his financial worth. In the summer of 1883, for instance, he objected to Iurgenson's fee for Mazepa, measuring its worth both in terms of the time it had taken to compose, and how it compared with other genres:

You know that I have never argued about the fees you have proposed, and indeed there was no reason to argue, since not only did you not offend me in this respect, but rather, or so it appeared to me, offended yourself, and I would often find that you were paying me too generously. Now something completely repellent has happened; the price you have named for Mazepa, is far from being fair, and I cannot let this go without protesting. If I

${ }^{27}$ Letter of 23-24 February/7-8 March 1882, in ibid., I, 357. 
am not mistaken, even for The Maid of Orleans I received from you more than 1000 rubles. But let us even suppose that it was 1000 rubles. But since then 4 years have passed. How can it be that my price over all this time hasn't increased one penny? [...] When you began to engrave The Maid, it wasn't clear that she would be staged; her fate was unknown. Now, then the opera houses in both capitals are competing to get the parts, scores, and piano reduction of Mazepa from you, you offer me 1000 rubles for an opera to which I have devoted 2 years and 3 months of constant work. [...] I suggest that in Mazepa there are hundreds of romances; it includes an entire symphonic scene; another symphonic number which is not without a future, and if one is to be logical, then it should bring me at least ten times more recompense than 10 songs or 10 worthless piano pieces. On the other hand, I know how difficult such large works are to sell when compared to small ones and for this reason I do not think that I am proposing anything unfair if I suggest the following price for Mazepa:

For the rights -2000 rubles

For the transcription 100 rubles per act 300.

For proof-reading 100

Total 2400 rubles. $^{28}$

Iurgenson's reply was as tactful as it was astute: "I have never liked my role in setting the price of your works; and I am very glad that you are taking advantage of your right to name yourself

${ }^{28}$ Letter of 28 July/9 August 1883, in ibid., I, 452. 
the reward you are due. This is a thousand times dearer to me..."29 The increasing profitability of Chaikovsky's works and his confidence in asserting his financial worth explain why he could withstand von Meck's sudden and unexplained withdrawal of his subsidy in 1890, however great its psychological impact. Yet this familiar narrative of growing celebrity and market appeal masks significant differences when it came to the comparative profitability of different musical genres, and Chaikovsky proved to be particularly sensitive to the tension between realizing immediate financial returns on his creative investments on the one hand, and the need to establish longer-term critical success on the other. This tension can best be analyzed by breaking down Chaikovsky's works by genre and considering the different kind of value that they bestowed.

\section{Artistic "manure": songs and instrumental miniatures}

Songs and small-scale instrumental works were central to the operation of Russia's nineteenthcentury market for classical music. Whilst Chaikovsky would sometimes turn to such works when otherwise lacking in inspiration or energy, they were also designed to underwrite his relationship with Iurgenson. Early in 1878, for instance, Chaikovsky reported that he had completed Evgeny Onegin and the Violin Concerto, and now planned to write a series of children's piece for piano (these would eventually become the Children's Album, op. 39): “This will be pleasant for me, and, for you, I think, even profitable, i.e. relatively. What do you think? In general, my friend, write and let me know what kind of small compositions I can particularly treat you to. I am very included at the moment, by way of relaxation, to busy myself with small-

\footnotetext{
${ }^{29}$ Letter of 29 July/10 August 1883, in ibid., I, 454.
} 
scale work." ${ }^{30}$ Then, in the summer of 1878, he finally invoiced Iurgenson for his latest compositions. Significantly, there is no mention of the major works from this period - Evgeny Onegin, the Fourth Symphony, or the Violin Concerto. Instead, he lists an extensive series consisting mainly of chamber instrumental works and songs:

Here is the fee that I'd like to receive for all of this:

1) for the Sonata - 50 rubles

2) for the 12 pieces at 25 each -300 rubles

3) for the children's album at 10 each - 240 rubles

4) for the 6 romances at 25 each -150 rubles

5) for the violin pieces at 25 each -75 rubles

6) for the liturgy - 100 [rubles]

In total -915 rubles, or a round sum of 900 rubles, but in view of the fact that I have written so much at all once, I will let you have it all for 800 rubles. $^{31}$

In proportion to their scale, ambition, and time taken to compose, the most lucrative works here are the Six Romances, op. 38, The Children's Album, op. 39, the Twelve Pieces, op. 40, and the three numbers for violin and piano that make up the Souvenir d'un lieu cher, op. 42. Such works appealed to a growing number of talented amateurs, many of whom had studied at Russia's new conservatories, and who formed Iurgenson's consumer base. By contrast, more ambitious and

\footnotetext{
${ }^{30}$ Letter of 14/26 February 1878, in ibid., I, 40.

${ }^{31}$ Letter of 29 July/10 August 1878, in ibid., I, 59.
} 
compositions such as the Piano Sonata, op. 37, and the Liturgy of St. John Chrysostom, op. 41, received nominal fees which reflected the fact that were unlikely to sell in large quantities. Chaikovsky does mention two other major works from this period - the Violin Concerto and Evgeny Onegin: "Are you agreed that by means of the opera I should repay you the debt of 500 rubles which I entailed by means of an opera. For the violin concerto I would like 50 rubles." ${ }^{32}$ Here, Onegin is monetized to pay off an earlier debt, while the concerto fetches only 50 rubles, precisely because it was less likely to sell extensively to the all-important amateur market, and its publication involved the production of a both a full score and orchestral parts.

Iurgenson was able to offer Chaikovsky substantial honoraria for his songs and piano works because after their publication such works yielded ongoing revenue for the publisher, yet brought nothing further for the composer. A substantial part of Iurgenson's catalogue was made up of such compositions and formed the basis on which he could undertake riskier artistic investments. ${ }^{33}$ Iurgenson was frank about the shortcomings of this repertoire, which formed the basis for an extensive exchange with Chaikovsky in September 1882: "Whilst your Trio is going through proofs, I have bought around 300 items of ready material from various publishers for 1000 rubles, with the plates all prepared. There is no music at all in these 300 items, mostly it's just manure, but in agriculture manure can be put to good use." ${ }^{34}$ Chaikovsky was rather uneasy about this idea, replying that:

\footnotetext{
${ }^{32}$ Ibid.

${ }^{33}$ See, for instance, the Polnyi katalog izdanii P. Iurgensona (Moscow, Leipzig, St Petersburg and Warsaw: Iurgenson, 1900).

${ }^{34}$ Letter of 11/23 September 1882, in Vaidman (ed.), P. I. Chaikovskii - P. I. Iurgenson: Perepiska, I, 378. For a list the various music publishers acquired by Iurgenon between 1870 and 1903, see Vol'man, 164.
} 
There are things about your business that I do not understand at all. Surely apart from a manic desire and avarice for any sort of engraved plates there can be no other inducement that would force you to pay 1000 rubles for the manure you discuss. Incidentally, the comparison with manure in this case is not relevant. In farming, manure is a most precious medium, responsible for the quality and quantity of fruit and vegetables which grow on it. But what fruit can the musical manure you have acquired bear? The only thing to happen is that your stores are several pounds heavier in metal - after all, music cannot cream off the foam from this shit. ${ }^{35}$

Iurgenson replied a few days later, advancing the metaphor yet further:

By "manure" I mean the many things that have value on the market, which bring in money and advance business. Let us suppose that "manure" is a "precious thing in farming," but it's still shit. [...] From the point of view of business, it is profitable to acquire these things, since they bring in profit. [...] I keep an account of when a piece is published and in what quantity - the rubbish sometimes sells in vast quantities. ${ }^{36}$

Evidence suggests that it was precisely this material that allowed Iurgenson to cultivate his relationship with Chaikovsky and to take risks on works that were less commercially viable. As Vol'man notes:

\footnotetext{
${ }^{35}$ Letter of 15/27 September 1882, in Vaidman (ed.), P. I. Chaikovskii-P. I. Iurgenson: Perepiska, I, 388.

${ }^{36}$ Letter of 20 September/2 October 1882, in ibid, I, 390.
} 
In printing everything that came from Chaikovsky's pen, Iurgenson consciously chose to make a loss and paid the composer a fee in accordance with the expectations of the day. [...] Chaikovsky was the only author to whom the publisher systematically paid relatively large sums. The remuneration paid by the publisher to other composers was much more modest, and only a selection of their works was printed. ${ }^{37}$

Although Chaikovsky could write dismissively of his songs and piano miniatures (he described the process of composing the 18 Pieces, op. 73, as being like turning out “musical pancakes"), ${ }^{38}$ he was clearly proud of his well-honed professionalism. Market-oriented such works may have been, yet he was nonetheless keen to assert a distinction between them and those mediocre compositions that were dictated by ephemeral, commercial concerns. ${ }^{39}$

\section{"For all of my prosperity I am obliged to the Petersburg Theater": Chaikovsky and the operatic stage}

Writing to Iurgenson in 1890, Chaikovsky observed that "for all of my prosperity I am obliged to the Petersburg Theater. Not only does it bring in 4 or 5 thousand rubles a year, but I also owe to

\footnotetext{
${ }^{37}$ Vol'man, 166.

${ }^{38}$ Letter of 15/27 April 1893, in Chaikovskii, Polnoe sobranie sochinenii, XVII (1891), 81.

${ }^{39}$ See too Iurgenson's account of his acquisition of works from the catalogue of Nikolai Bernard in the summer of 1885: "What do you think about this acquisition? It's not exactly the Russian classics of Stellovsky, but there's a lot of good stuff there. For instance, 12 pieces and 4 songs by Chaikovsky! 74 romances by Dargomyzhsky, 13 romances by Glinka, 24 romances and 14 pieces by Rubinstein, and a mass of pitiful but profitable things." Letter of 7/19 September 1885, in Vaidman (ed.), P. I. Chaikovskii-P. I. Iurgenson: Perepiska, I, 520.
} 
it my pension of 3000 rubles, and also my reputation as a composer."40 Given Iurgenson's unwavering support for him since the mid-1860s, this was a tactless observation (compounded by Chaikovsky's occasional habit of presenting his manuscripts to other people, when by rights they belonged to Iurgenson), yet it reflects the substantial source of income that opera had come to represent for Chaikovsky by the 1890s. Iurgenson paid handsomely for the right to publish these scores (2000 rubles for Mazepa, 3000 for The Enchantress, 5000 for Queen of Spades, and 5000 for Iolanta, originally commissioned as part of a single evening's entertainment alongside The Nutcracker), primarily because of the prestige which such Imperial commissions carried, but also because sales of scores and parts offered a nominal return on his investment.

The Imperial Theaters Directorate, which administered the operation of the Mariinsky Theater in Petersburg and the Bol'shoi Theater in Moscow, had a strict set of rules governing the share of box-office income that composers could expect to earn (typically 8-10\% of the daily takings, what was referred to as the "pospektakl'naia plata" or "payment per performance"). Accordingly, an opera that appealed successfully to paying audiences could represent a substantial source of additional income, as Chaikovsky's accounts reveal (table 2).

PETERBURG:

26 March 1884: 1146 rubles, 58 kopeks

25 December 1885: 188 rubles

28 March 1888: 853 rubles, 46 kopeks

6 April 1888: $\quad 288$ rubles, 72 kopeks

10 May 1889: 2038 rubles, 96 kopeks

${ }^{40}$ Letter of 4/16 June 1890, in ibid., II, 290. 
29 March 1890: 1749 rubles, 85 kopeks

29 April 1890: 1093 rubles, 29 kopeks

26 May 1890: $\quad 250$ rubles

MOSCOW:

12 March 1884: 998 rubles, 67 kopeks

21 May 1884: $\quad 73$ rubles, 73 kopeks

5 March 1886: 2233 rubles, 67 kopeks

12 May 1887: 1629 rubles

13 July 1887: $\quad 633$ rubles, 12 kopeks

28 March 1888: 1035 rubles, 20 kopeks

24 April 1889: 1669 rubles, 34 kopeks

19 March 1890: 1190 rubles, 43 kopeks

22 June 1890: 1319 rubles

7 February 1891: 263 rubles, 84 kopeks

7 May 1893: 1091 rubles, 46 kopeks

TABLE 2: Chaikovsky's income from the Petersburg and Moscow branches of the Imperial Theater Directorate. Source: Chaikovksy State House Museum, Klin.

Chaikovsky's relationship with the Directorate requires greater study; it is clear that he enjoyed behind-the-scenes support from leading figures in the Imperial administration as a result of his connections to the Romanov dynasty. Yet if his success in the Russian capitals cannot simply be 
put down to the disinterested operation of the market, the situation in the provinces suggests that his works were genuinely popular with paying audiences. This was particularly the case after 1882, when the Imperial Theaters Directorate lost its monopoly on stage productions throughout the Empire. As a result, independent entrepreneurs set up business in important urban centers, where the repertoire that they favored was more obviously determined by popular taste. ${ }^{41}$ Even where Chaikovsky's operas were staged in theaters that enjoyed state support (as in Tbilisi), or were put on by provincial branches of the Russian Musical Society, the limited financial means available to such bodies meant that audience appeal played an important role when it came to repertoire. As with theaters in Petersburg and Moscow, Iurgenson handled the income that Chaikovsky earned from performances of his operas in provincial theaters, although such theaters often paid a one-off fee for each performance, rather than a share of the box-office takings (table 3$)$.

7 February 1884: 93 rubles, 45 kopeks (Tbilisi and Kharkiv)

6 December 1885: 100 rubles (Kazan')

27 February 1886: 75 rubles (Kazan')

18 May 1887: $\quad 50$ rubles (Tbilisi)

8 October 1887: 329 rubles (Kyiv)

19 January 1888: 125 rubles (Tbilisi)

21 January 1888: 90 rubles (Vilnius)

27 October 1888: 125 rubles (Tbilisi)

7 December 1888: 125 rubles (Kyiv)

\footnotetext{
${ }^{41}$ Frame, pp. 74-106.
} 


\author{
28 January 1889: 210 rubles (Kazan') \\ 22 February 1889: 300 rubles (Tbilisi) \\ 13 March 1889: 200 rubles (Tbilisi) \\ 5 May 1889: 192 rubles, 10 kopeks (Kharkiv) \\ 7 June 1889: $\quad 72$ rubles, 25 kopeks (Kharkiv) \\ 28 June 1889: $\quad 90$ rubles (Vilnius) \\ 4 July 1889: $\quad 68$ rubles (Odessa) \\ 10 July 1889: $\quad 90$ rubles (Vilnius) \\ 31 July 1889: $\quad 90$ rubles (Vilnius) \\ 17 August 1889: 90 rubles (Vilnius) \\ 15 September 1889: 120 rubles (Vilnius) \\ 25 September 1889: 75 rubles (Vilnius) \\ 21 October 1889: 91 rubles, 80 kopeks (Kyiv) \\ 6 November 1889: 75 rubles (Vilnius) \\ 18 January 1890: 258 rubles, 40 kopeks (Kharkiv) \\ 19 January 1890: 135 rubles (Vilnius) \\ 9 March 1890: $\quad 60$ rubles, 20 kopeks (Kharkiv) \\ 18 March 1890: 250 rubles (Tbilisi) \\ 24 June 1890: $\quad 25$ rubles (Kazan') \\ 22 August 1890: $\quad 75$ rubles (Vilnius) \\ 26 October 1890: 75 rubles (Vilnius) \\ 10 November 1890: 99 rubles, 25 kopeks (Kazan') \\ 19 December 1890: 75 rubles (Vilnius)
}


26 January 1891: 293 rubles, 40 kopeks (Kharkiv), 75 rubles (Vilnius), 125 rubles $\left(\right.$ Kazan') $^{\prime}$

21 February 1891: 50 rubles (Saratov), 150 rubles (Kazan')

28 February 1891: 25 rubles (Kazan')

13 March 1891: 125 rubles (Tbilisi)

28 March 1891: $\quad 45$ rubles (Vilnius)

9 May 1891: $\quad 285$ rubles, 60 kopeks (Kharkiv)

20 May 1891: $\quad 50$ rubles (Samara)

21 May 1893: $\quad 100$ rubles (Tbilisi)

5 June 1893: $\quad 23$ rubles, 40 kopecks (Kazan')

14 June 1893: $\quad 200$ rubles (Orenburg)

TABLE 3: Income from performance of Chaikovsky's operas outside Petersburg and Moscow. Source: Chaikovsky State House Museum, Klin.

The work that was central to Chaikovsky's fortunes - both literal and metaphorical - was, of course, Evgeny Onegin. At first glance, this is a paradoxical claim, given that Chaikovsky wrote the opera with no expectation of an official commission and set himself against the established conventions of the day. Yet as he wrote to Iurgenson, he believed that for all its unconventionality, Onegin would - eventually - appeal directly to the tastes of music-lovers:

This opera will, it seems to me, soon enjoy success in homes, and perhaps, on the concert platform, more so than on the main stage, and for this reason, the fact that it will be 
published much earlier than enters the repertoire of the main theaters is not unfavorable. The success of this opera should begin from below, and not from on high. I.e., it is not the theater that will make it well known to the public, but the other way round, that the public, having slowly become familiar with it, may fall in love with it, and then a theater might stage the opera, in order to satisfy the demands of the public. ${ }^{42}$

Chaikovsky refused to give his new opera to the main stage ("with its routine and conventionality, with its talentless directors and its senseless, albeit luxurious productions, with its signaling machines instead of conductors"), ${ }^{43}$ preferring instead to entrust it to what he saw as the good sense of Russia's musical public. The popular audience's slow infatuation with Evgeny Onegin can be traced in its early performance history:

- Dress rehearsal of first four scenes, Moscow Conservatory, December 1878

- $\quad$ Extracts performed at the Petersburg home of Iuliia Abaza, March 1879

- $\quad$ Student performance, Moscow Maly Theater, March 1879

- $\quad$ Concert performances of extracts, St. Petersburg, January and March 1880

- $\quad$ Professional stage premiere, Bol'shoi Theater, Moscow, January 1881

- $\quad$ Performed at Kononov Musical-Dramatic Theater, St. Petersburg, April 1883

- $\quad$ Performed at Kharkiv Opera House, October 1883

- Performed at Kyiv Opera House, October 1884

- Premiere at Mariinsky Theater, St. Petersburg, October 1884

\footnotetext{
${ }^{42}$ Letter of 4/16 February 1878, in Vaidman (ed.), P. I. Chaikovskii-P. I. Iurgenson: Perepiska, I, 39.

${ }^{43}$ Letter of 3/15 December 1877, in Chaikovskii, Polnoe sobranie sochinenii, XI (1961), 275.
} 
- New production, Mariinsky Theater (with a newly composed ecossaise in Act III), September 1885

This theatrical reception was accompanied and even anticipated by a parallel process of publication and performance outside of the capitals' main theaters (as Boris Gasparov notes, by the time that Evgeny Onegin appeared on the stage of St. Petersburg's Mariinsky Theater, the opera "had already started its triumphant march through provincial opera houses, concert halls, and private living rooms"). ${ }^{44}$ A piano reduction of the score was passed for publication as early as September 1878, well before the opera received its first professional stage performance, and the full orchestral score followed two years later. A number of individual numbers were also published separately. This almost appears to have been a deliberate strategy pursued by Iurgenson, who intuited the potential power of everyday music lovers to influence the Imperial Theaters Directorate. ${ }^{45}$

Onegin's success abroad was no less significant when it comes to Chaikovsky's financial solvency. Iurgenson's accounts detail twelve payments over a two-year period in respect of performances of the opera in Prague (table 4).

\footnotetext{
${ }^{44}$ Boris Gasparov, Five Operas and a Symphony: Word and Music in Russian Culture (New Haven and London: Yale University Press, 2005), 59.

${ }^{45}$ For details of the earliest performances and publications of the opera, see Polina Vaidman, Liudmila Korabel'nikova, and Valentina Rubtsova (eds), Tematiko-bibliograficheskii ukazatel' sochinenii P. I. Chaikovskogo, 2nd edn (Moscow: P. Iurgenson, 2006), pp. 80-81, and Alexander Poznansky and Brett Langston (eds), The Tchaikovsky Handbook: A Guide to the Man and His Music, 2 vols (Bloomington and Indianapolis: Indiana University Press, 2002), I, 38-40.
} 
1 January 1889: 197 rubles, 88 kopeks

23 January 1889: 60 rubles, 50 kopeks

24 February 1889: 28 rubles, 40 kopeks

26 April 1889: 166 rubles, 20 kopeks

26 October 1889: 34 rubles, 33 kopeks

28 November 1889: 46 rubles, 20 kopeks

21 December 1889: 28 rubles, 35 kopeks

27 January 1890: 24 rubles, 40 kopeks

23 February 1890: 26 rubles

29 March 1890: 43 rubles, 45 kopeks

25 April 1890: $\quad 36$ rubles

27 October 1890: 29 rubles, 23 kopeks

TABLE 4: Income from Prague performance of Evgeny Onegin. Source: Chaikovsky State House Museum, Klin.

Prague had, in fact, seen the first performance of any Chaikovsky opera abroad (a production of The Maid of Orleans in 1882), but it was the production of Evgeny Onegin that opened there in late 1888 which laid the foundations for subsequent productions in cities such as Hamburg, Vienna, and London. Indeed, it was growing interest in Chaikovsky's operas in Western Europe that led Iurgenson to negotiate an agreement with the German operatic entrepreneur, Bernhard 
Pollini, in 1890 that covered performance in the German-speaking lands. ${ }^{46}$ As the fees paid to Chaikovsky by the Imperial Theaters Directorate, Russia's provincial theaters, and even a growing number of foreign companies suggest, the risks of writing an opera, whether in terms of the time and effort required to compose one in the first place, or in terms of the subsequent complexities of getting one published and performed, were offset by correspondingly substantial potential rewards. Given the social prestige and critical canonicity that opera held in nineteenthcentury Russia, Chaikovsky's attraction to the genre is to be expected; more surprising, perhaps, is the extent to which his artistic convictions mapped so closely onto his economic wellbeing.

\section{Symphonic music and the Russian Musical Society}

Opera and ballet were lavishly supported by the Imperial exchequer and were central to the ways in which the Romanov dynasty had, almost literally, "staged" its claim to power from the eighteenth century onwards. ${ }^{47}$ At the other end of the scale, domestic music-making was an intimate reflection of the importance of music in the everyday lives of the aristocracy, gentry, and growing urban middle-classes. ${ }^{48}$ Symphonic music, by contrast, occupied a more ambiguous place within musical life in nineteenth-century Russia. In the first half of the century, orchestral concerts had been a largely occasional affair. With the foundation of the Russian Musical

\footnotetext{
${ }^{46}$ M. G. Raku, "Bernkhard Pollini kak zarubezhnyi impresario Chaikovskogo," Iskusstvo muzyki: teoriia i istoriia, 3 (2012): 80-103.

${ }^{47}$ Richard Wortman, Scenarios of Power: Myth and Ceremony in Russian Monarchy, 2 vols (Princeton: Princeton University Press, 1995-2000).

${ }^{48}$ Julia Mannherz, "Nationalism, Imperialism and Cosmopolitanism in Russian Nineteenth-Century Amateur MusicMaking,” Slavonic and East European Review, 95/2 (2017): 293-319.
} 
Society in 1859 , things were put on a firmer footing, although as Iurgenson's letters make clear, the Society frequently struggled to balance its books or sell all its tickets, let alone turn in any kind of profit. Nonetheless, the Society proved to be an important source of income for Chaikovsky. Moreover, because Iurgenson was a member of the board of the society, there is an overlap between his professional interests as a businessman and his administrative commitments as a representative of a leading Imperial institution.

Chaikovsky was faced with something of a dilemma when it came to the composition of symphonic works; whilst orchestral scores - particularly symphonies, but also concertos and symphonic poems - played an important role in establishing critical success, they were timeconsuming to compose and an uncertain proposition when it came to box-office income, the sale of scores and parts, and even repeat performances. Writing to Iurgenson about Manfred, for instance, Chaikovsky revealed himself to have a firm understanding of the operation of the market for such works:

Manfred, even if it is a work of genius, is the kind of symphony that because of its unusual complexity and difficulty can be played only once every ten years; for this reason, it cannot make any money for you [...]. On the other hand, I value it very highly, but how can one put a price on such a thing in money? Perhaps I am mistaken, but it seems to me that it is my best work; I invested so much labor and suffering that several hundred rubles seem to me unworthy and incapable of rewarding my labors. If you were very rich, I would perhaps have no compunction in naming a very substantial sum on the basis that 
you could make up for the outlay in some other way - but the fact is that you are not rich. $^{49}$

Here, there is an obvious slippage between the economic and metaphorical use of words such a value, worth, price, and significance. Orchestral music may have offered critical prestige, yet it was effectively a "loss-leader" for both composer and publisher when it came to reliable income. For all the effort that went into the conception, composition, and orchestration of Chaikovsky's symphonic works, the fees that Iurgenson offered for them were notably lower than those for operas, and were even outstripped by those paid for albums of songs and piano miniatures (table $5)$.

\begin{tabular}{|l|l|}
\hline Suite No. 1, op. 43 & 100 rubles \\
\hline Piano Concerto No. 2, op. 44 & 500 rubles \\
\hline Capriccio Italien, op. 45 & 100 rubles \\
\hline Serenade for Strings, op. 48 & 100 rubles \\
\hline Moscow and Coronation March & 500 rubles \\
\hline Suite No. 2, op. 53 & 500 rubles \\
\hline Suite No. 3, op. 55 & 300 rubles \\
\hline Concert Fantasia, op. 56 & 200 rubles \\
\hline Mozartiana, op. 61. & 500 rubles \\
\hline Pezzo capriccioso, op. 62 & 100 rubles \\
\hline
\end{tabular}

${ }^{49}$ Letter of 22 December 1885/3 January 1886, in Vaidman (ed.), P. I. Chaikovskii - P. I. Iurgenson: Perepiska, I, 520-30. 


\begin{tabular}{|l|l|}
\hline Symphony No. 5, op. 64 & 500 rubles \\
\hline Hamlet, op. 67 & 500 rubles \\
\hline
\end{tabular}

TABLE 5: Fees paid by Iurgenson for Chaikovsky's orchestral works. Source: Chaikovsky State House Museum, Klin; and P. E. Vaidman (ed.), P. I. Chaikovskii - P. I. Iurgenson: Perepiska, 1866-1893, 2 vols (Moscow: P. I. Iurgenson, 2011-13).

Similarly, the fees that Chaikovsky received from the Russian Musical Society were more nominal than substantial. The fee of 300 rubles that he received in 1873 for his orchestral fantasy, The Tempest, seem to have been anomalously large, as were the sums of 200 rubles and 100 rubles that he was paid by the Moscow and Petersburg branches of the Russian Musical Society respectively for his First Suite in $1880 .{ }^{50}$ Indeed, these fees may possibly have been the result of some lobbying by Iurgenson on Chaikovsky's behalf; the previous year, Chaikovsky complained that whilst the Petersburg branch of the society had introduced payment for performances of works by Russian composers, the Moscow branch refused (on the grounds that composers had already received payment for the publication of their scores). ${ }^{51}$ Thereafter, the situation seems to have been regularized, and the sums that Chaikovsky earned from performances of his works at the society's concerts were included more systematically in his accounts with Iurgenson (table 6).

\footnotetext{
${ }^{50}$ Undated letter [December 1873] and letter of 14/26 February 1880, in Vaidman (ed.), P. I. Chaikovskii - P. I. Iurgenson: Perepiska, I, 21 and 195.

${ }^{51}$ Letter of 8/20 November 1879, in ibid., I, 173.
} 
7 February 1884: 130 rubles

30 August 1884: 455 rubles

2 October 1887: 175 rubles

17 December 1888: 420 rubles

30 September 1889: 200 rubles

31 August 1890: 150 rubles

TABLE 6: Fees paid by the Moscow and Petersburg branches of the Russian Musical Society. Source: Chaikovsky State House Museum, Klin.

The fact that the Russian Musical Society was less a moneymaking enterprse than an arm of the state's cultural policy means that these figures cannot be interpreted commercially. Given the often precarious nature of the society's finances, such sums constitute a substantial part of its outgoings and represent both an implicit investment in Chaikovsky's career and an attempt to capitalize on his critical reputation. From Chaikovsky's point of view, the income derived from the society was less than what could be brought in by performances of his operas and the publication of songs and instrumental works, yet the inferior financial rewards that symphonic works offered were offset by their artistic significance. The Russian Musical Society supported Chaikovsky in indirect ways too. After the failure of his marriage in summer 1877 and subsequent flight to Western Europe, he was supported by the society to the tune of 100 rubles a month ("at the present exchange rate it's not much money - but it's money all the same, and it 
means that I am sufficiently set up so that I probably won't starve to death"). ${ }^{52}$ Then, in the spring of 1880 , he sought to pay off a number of debts either by borrowing money from the society against future performances of his latest opera, The Maid of Orleans, or by giving up the next four payments of 300 rubles he could expect to receive from it annually in favor of a single payment of 1000 rubles. ${ }^{53}$ In December of 1882, he borrowed another 500 rubles from the Society, which he hoped to pay off by means of the fee he was due to receive for performance of his works over the 1882/83 season, as well as by the royalties from The Maid of Orleans. ${ }^{54}$ The Russian Musical Society was evidently keen to accede to such demands in order to assure itself of the presence of Chaikovsky's works in its programs and thus share in his artistic capital.

If, in Russia, opera, song, and chamber instrumental music formed a very substantial part of Chaikovsky's income, Western Europe and Northern America showed greater interest in his symphonic works, which could be incorporated into established concert series in the major metropolitan centers and performed in a growing number of purpose-built concert venues. ${ }^{55}$ Although some of his songs and instrumental and chamber works were published in the West in his lifetime, it was primarily through works such as Romeo and Juliet, Francesca da Rimini, the

\footnotetext{
${ }^{52}$ Letter of 28 October/9 November 1877, in ibid., I, 27. See too Chaikovsky's request to draw in advance the money he was due to receive for June, July, and August 1878 in his letter of 1/3 January 1878, in ibid., I, 34.

${ }^{53}$ Letter of 27 March/8 April 1880, in ibid., I, 203.

${ }^{54}$ Letter of 14/26 April 1883, in ibid., I, 449.

${ }^{55}$ On the Western discovery of Russian music, see Inga Mai Groote, Östliche Ouvertüren: Russische Musik in Paris 1870-1913 (Kassel: Bärenreiter, 2014), Philip Ross Bullock, Rosa Newmarch and the Reception of Russian Music in Late Nineteenth and Early Nineteenth-Century England (Farnham: Ashgate, 2009), and Elaine Brody, "The Russians in Paris (1889-1914)," in Malcolm Hamrick Brown (ed.), Russian and Soviet Music: Essays for Boris Schwarz (Ann Arbor: UMI Research Press, 1996), 157-83.
} 
Piano Concerto No. 1, the Suite No. 3, the fourth, fifth, and sixth symphonies, and even the Violin Concerto (famously denounced by Eduard Hanslick on the occasion of its premiere in Vienna in 1881) that Chaikovsky's name became known outside of his homeland. The early phase of Chaikovsky's reception in the West was dependent on a small group of enthusiastic conductors who were prepared to lend their own reputation in the service of this still unfamiliar repertoire. Thereafter, it was Chaikovsky's decision to conduct his own works that cemented their place in the orchestral canon. This decision had both artistic and economic implications, since it was the composer's presence on the rostrum that permitted the payment of often substantial performing fees. In particular, The Third Suite proved to be a calling card for its composer on foreign tours, and he included its finale in concerts that he gave in Hamburg, Prague, Paris, and London in 1888. The whole suite featured in concerts he conducted thereafter, including at the opening of New York's Carnegie Hall during his 1891 American tour. As he observed in a letter to Iurgenson, 'My 3rd suite is, I think, the most gratifying of all my orchestral works for foreign audiences. ${ }^{, 56}$

Yet there was a tension between critical success and economic costs, as Chaikovsky explained to Iurgenson in March 1888:

Both of Colonne's concerts were a brilliant success, and my fame has increased awfully, but I didn't receive any money and won't receive a kopek, quite the opposite - I am spending more than ever. It's the last time I travel alone; in future I shall bring a secretary to take care of all my profits. During this time I have wasted a lot of money and even more strength and health - and I have acquired some fame, but every minute I ask myself:

\footnotetext{
${ }^{56}$ Letter of 30 March/11 April 1891, in Vaidman (ed.), P. I. Chaikovskii-P. I. Iurgenson: Perepiska, II, 371.
} 
why, is it all worth it, and so on? And then I come to the conclusion that to live without fame, but quietly, is much better than leading this crazy life. ${ }^{57}$

On his return to the Russian Empire, Chaikovsky had further occasion to reflect on both the costs and the advantages of his recent trip:

Of course, I regret the vast amount of money spent on the trip, but either one should not go at all, or pay from one's own pocket. Of course, this won't be the case in the future. And imagine, as soon as is I was ready to spit on everybody and had resolved to head home, I am suddenly overwhelmed with financial propositions: from Angers - a fee of 1000 francs, from Geneva, the same; in London at the Crystal Palace an uncertain sum but I resolutely declined it all. You are mistaken about the outcome of my trip: in London I received not 20 , but 25 pounds (thanks to the great success the directors added a tip of 5 pounds), and you haven't counted the 500 marks in Hamburg. But, of course, from a financial point of view, the trip was pitiful - but then again, I didn't go on account of the money. ${ }^{58}$

At this point in his career, Chaikovsky's financial situation within Russia was largely secure, so he could afford to undertake foreign tours in the hope of gaining a reputation with critics and audience, even if the immediate financial return was minimal.

\footnotetext{
${ }^{57}$ Letter of 1/13 March 1888, in ibid., II, 126.

${ }^{58}$ Letter of 28 March/9 April 1888, in ibid., II, 132,
} 
In fact, Chaikovsky's tours could constitute something of a sticking point in his relations with Iurgenson. Performances of his symphonic works represented an opportunity to sell copies of both score and parts to foreign orchestras and philharmonic societies, yet it seems that Chaikovsky would sometimes use his own materials, thereby depriving Iurgenson of potential income. After Chaikovsky's tour of Europe in the spring of 1889, Iurgenson gently upbraided him on this account:

When I wrote to you, I told you about the score and parts of the work that you were to perform in London. I, in a spirit of pettiness, wanted to derive some benefit from the orchestral material; you deprived me of a sale of parts to those societies in those cities where you conducted. The sum ought to be quite substantial. Finally, in London, I warned you, and still I didn't manage it!

That's all water under the bridge. But I would ask you, remember this and tell them, when you are agreeing terms, from whom they should acquire the score and parts. That's up to them. [...] In the end, even if it's more convenient for you to play from your own music, this doesn't prevent them from having their own copy. And after all, carrying so many parts around with you must cost a hell of a lot of money. ${ }^{59}$

In his reply, Chaikovsky defended himself, pointing out the complexities of dealing with European orchestras, and highlighting the tension between his role as conductor and composer on the one hand, and as Iurgenson's agent on the other:

\footnotetext{
${ }^{59}$ Letter of 20 April/2 May 1889, in ibid., II, 209.
} 
Can I demand that they buy the parts, when I cannot play from them on account of the large number of errors? [...] And, given the state of my nerves and anxieties, and the nature of my travels and so on, it is impossible to negotiate about parts and scores too. [...] But there is nothing easier than to deduct the cost of them from me, since I received a fee, both for conducting and for the scores. And so, I think it would be fair if you deducted the cost of the Serenade, Mozartiana, and the 1st Suite from my account. ${ }^{60}$

Because Chaikovsky typically received a one-off fee for the right to publish his works, he could afford to be careless when it came to the sale of scores and parts, even if he risked souring his relationship with Iurgenson by depriving him of a potential source of commercial revenue.

This situation was exacerbated by the lack of any formal copyright agreement between the Russian Empire and the rest of the world. Foreign performances may have played an important role in raising the profile of Chaikovsky's works in important cultural centers, yet foreign performers and publishers were not bound by enforceable arrangements that could guarantee both his and Iurgenson's economic interests. This situation was, in part, mitigated by agreements that Iurgenson signed with foreign publishers. Félix Mackar, for instance, paid Iurgenson 20000 francs for the right to publish Chaikovsky's works in France in 1885 (the sum was split equally between the composer and his Russian publisher), and Iurgenson enjoyed a long-standing relationship with Daniel Rahter that covered Chaikovsky's compositions in the German-speaking world. Yet even if such agreements offered some protection abroad, it did not always prevent publishers from making their own editions of Chaikovsky's works. German editions of Chaikovsky's works were also published by Klindworth and Fuerstner, and a French

${ }^{60}$ Letter of 26 April/8 May 1889, in ibid, II, 209-10. 
edition of The Seasons (published under the title of Tableaux du Nord) appeared in Paris in 1883, although it was unclear whether this was a pirated score, or whether it reflected a legitimate agreement with the work's original publisher, Bernard. ${ }^{61}$ Iurgenson's own activities in Russia were further complicated by the ambiguities inherent in international copyright agreements. In 1883, he enlisted Chaikovsky, who was then in Paris, to investigate claims that he had infringed the rights of the French publisher of Gounod's Faust (the French Sociétié des auteurs et compositeurs dramatiques was assiduous in pursuing the interests of its members). Iurgenson eventually paid up, but commented bitterly on the seeming disparity between the situations in Russia and Western Europe: "How strange it is that a Parisian publisher can threaten me, but I can do no nothing in my country against the import of German editions of Chaikovsky and Rubinstein into Russia." ${ }^{62}$

So why pursue relationships with foreign publishers at a time when the commercial prospects seemed so uncertain? Here, the trade-off was one between financial interest and critical affirmation, where the aspiration of winning the latter obscured the risks entailed by pursuing the former. By the 1880s, Chaikovsky's reputation was largely established within the Russian Empire, and Iurgenson's astute management of his various artistic relationships - with amateur performers, paying audiences, the Imperial Theaters Directorate, and the Russian Musical Society - meant that his finances were increasingly secure. At this point, success abroad became as important as success as home, as the story of official Russian involvement in the various World Expositions suggests. Affirmation in the major metropolitan centers for art music in Western Europe - Berlin, Vienna, Paris, even London - constituted an important additional

\footnotetext{
${ }^{61}$ Letter of 26 February-1 March/10-13 March 1883, in ibid., I, 426.

${ }^{62}$ Letter of 7-8/19-20 March 1883, in ibid., I, 433.
} 
factor in Chaikovsky's domestic success, as well as a broader investment in the reputation of the Russian arts. ${ }^{63}$

\section{Chaikovsky and the exercise of patronage}

Chaikovsky's wealth, obscured in previous accounts of his life by an excessive emphasis on his debts and seeming financial incompetence, meant that he found himself able to support others. Many of these individuals were close friends or family members. He regularly had Iurgenson send money to his younger brother, Modest, who, as a struggling playwright, knew little of his more famous brother's worldly success (he did, though, receive a share of the credit for Queen of Spades and Iolanta, for which he provided the libretti) ${ }^{64}$ Chaikovsky sent money to Nikolay Bochecharkov, an old friend from Moscow's gay demi-monde, as well as to the violinist, Iosef Kotek, a friend and possibly one-time lover (after Kotek's death, he would provide for his sister and brothers) ${ }^{65}$ In early 1883 , Chaikovsky took responsibility for looking after his niece, Tania, who had fallen pregnant by her piano teacher. He took her to Paris for the delivery of her child,

${ }^{63}$ On the importance of Paris as a center for the legitimation of Europe's "peripheral" cultures, see Pascale Casanova The World Republic of Letters, trans. M. B. DeBevoise (Cambridge, MA, and London: Harvard University Press, 2004).

${ }^{64}$ Payments to Modest are recorded in an undated letter [September 1874] and in a letter of 2/14 May 1881, in Vaidman (ed.), P. I. Chaikovskii - P. I. Iurgenson: Perepiska, I, 21 and 266.

${ }^{65}$ For instructions relating to payments to Bocherkarkov, see letters of 27 November/9 December 1887, 14/26 April 1878, 8/20 August 1878, 20 October/1 November 1878, 28 December 1878/9 January 1879, and 18 February/2 March 1879, in ibid., I, 31, 49, 61, 65, 89, and 114. For payments to Kotek and his family, see letters of 26 July/7 August 1877, 1-4/13-16 January 1888, 3/15 October 1889, 6/18 February 1891, 11/23 November 1891, in ibid., I, 25, and II, 115, 216-7, 355, and 394. 
not only paying for her medical treatment, but also arranging for the child, Georges-Léon, to be placed with a French foster couple (he would eventually be adopted by Chaikovsky's older brother, Nikolay, and his wife, Ol'ga). ${ }^{66}$ Most of all, however, Chaikovsky's greatest financial obligations were to his wife, Antonina, despite Iurgenson's regularly repeated warning to limit his commitments:

Your remarks about the size of the subsidy I give my spouse are entirely correct, but I would just say one thing. The more, the better, since the less I am connected with her, the calmer I shall feel. It is I who would be patient because of my stupidity. Only by means of money can I buy myself the right to scorn her as much as I hate her. ${ }^{67}$

Chaikovsky's initial subsidy of 50 rubles a month in 1878 increased as his own income grew, especially after it became apparent that Antonina was unwilling to agree to a divorce. He doubled his payment in 1888 , increasing it to 150 rubles just one year later, and he would make occasional additional payments to her when he felt particularly well-off. ${ }^{68}$

Equally significant is Chaikovsky's provision for members of Russia's cultural community. He provided regularly for his first piano teacher, Mariia Palchikova, and made

\footnotetext{
${ }^{66}$ The affair is traced in letters of 29 January-2 February/10-14 February 1883, 25 March/6 April, 11/23 May 1884, 19/31 August 1884, 4/16 March 1885, and 13/25 September 1885, in ibid., I, 415-6, 439, 484, 495, 512, and 524. 
occasional payments to his friend, German Larosh (Herman Laroche), and his mother, Sofiia. ${ }^{69}$ When Nikolay Kashkin found himself in substantial debt in 1887, Chaikovsky not only provided for him from his own resources, but also intervened to facilitate further help from Pavel Tret'iakov. ${ }^{70} \mathrm{He}$ also made provision for a piano teacher, Anna Levinson (also known by her married name of Aleksandrova) when she fell pregnant in 1885, supporting her occasionally thereafter. ${ }^{71}$ Iurgenson could find Chaikovsky's generosity irksome and was dismissive of those he deemed unworthy "hangers-on”. Of Anna Levinson, for instance, he asked: "How you can put up with her and her effrontery I cannot understand." 72 And when Chaikovsky complained, once again, of being short of money, Iurgenson wryly noted: "Your kind nature leads you to make payments you cannot afford... If, for a while, you can refrain from charitable impulses, then I hope equilibrium will be restored." ${ }^{\text {73 }}$ Chaikovsky's frequent financial difficulties made him sensitive to others in a similar position, and as his situation first stabilized and then improved (and public knowledge of his wealth began to spread), he showed himself ever more willing to extend to others the kind of generosity on which he himself had once been dependent. His susceptibility contrasts with Iurgenson's more hard-hearted approach to money, but it is also true

\footnotetext{
${ }^{69}$ Payments to Palchikova are recorded in letters of 9/21 January 1883, 14/26 September 1887, 15/27 March 1888, and 11/23 August 1888, in Vaidman (ed.), P. I. Chaikovskii - P. I. Iurgenson: Perepiska, I, 408, II, 88, 130, and 151. For payments to Larosh and his mother, see letters of 13/25 October 1887, 17 February/1 March 1890, and 26-27 February/10-11 March 1890, in ibid., II, 101, 240, and 245.

${ }^{70}$ Letter of 12/14 November 1887, in ibid., II, 103.

${ }^{71}$ See, for instance, letters of 26 April/8 May 1885, 17/29 July 1890, and 17/29 March 1891, in ibid., I, 514, II, 302, and 367 .

${ }^{72}$ Letter of 19/31 July 1890, in ibid., II, 302.

${ }^{73}$ Letter of 5-6/17-18 February 1890, in ibid., II, 232.
} 
that Chaikovsky would never have enjoyed the luxury of kindness had it not been for his publisher's shrewd management of his talent and reputation in the first place.

If many of Chaikovsky's charitable instincts were determined by personal circumstances, others instances of generosity suggest that he was keen to repay the kind of debts that had made his musical career possible in the first place. He provided scholarships for a number of students at the Moscow Conservatory; there are references to a pianist, Viktoriia Miller, studying at his expense in 1884 and again in 1887, and to Sergei Borisoglebsky (a baritone who went on to enjoy a career at both the Bol'shoi and Mariinsky theaters), in 1888 and again in 1890 (one of three students he was supporting by this time at a cost of 600 rubles a year). ${ }^{74}$ Chaikovsky could also intervene in Iurgenson's business practice, although not always to his publisher's satisfaction. In 1881, the composer recommended Mikhail Klimenko, a young clerk who wanted to escape life in Kamenka. ${ }^{75}$ Initially, Iurgenson was impressed with his new charge (whilst noting that "I hope that once you have set him up, you will leave him to live according to his own means and won't advance him any credit in secret"). ${ }^{76}$ Klimenko reappears in Chaikovsky’s letters in 1890, this time suffering from tuberculosis; the composer had Iurgenson send him 25 rubles in early February, followed by a further 100 rubles a few weeks later. ${ }^{77}$ Later that year, however, Chaikovsky's warm-heartedness set him at odds with his friend and publisher. Iurgenson had been made aware that Chaikovsky had paid the engravers of the score of Queen of Spades himself and wrote to object:

\footnotetext{
${ }^{74}$ Letters of 7/19 February 1884, 3/15 October 1887, 30 March/11 April 1888, 7/19 April 1888, 22 January/3

February 1890, and 28 January/9 February 1890, in ibid., I, 472, and II, 95, 135, 137, 227, and 229.

${ }^{75}$ Letter of 11/23 October 1881, in ibid., I, 298-9.

${ }^{76}$ Letter of 14/26 October 1881, in ibid., I, 291.

${ }^{77}$ Letters of 2/14 February 1890 and 23 February/7 March 1890 in ibid, II, 231 and 243.
} 
You, I have heard, have rewarded my engravers above their dues. To tell you the truth, you should not have done that - after all, I pay them for their work, and pay them almost three times what they received before, and the foremen know no want, and tipping them like this merely spoils them, since there can be no benefit from chance income. ${ }^{78}$

Chaikovsky was unrepentant, showing admiration for the engraver's skill and labor and challenging Iurgenson's moral precepts:

I rewarded the engravers very moderately; I do this very rarely (never since The Enchantress), and it seems to me fair to offer such laborers a certain reward (10 kopeks per plate) for their fine work - it's not a bad thing at all, so forgive me, but I will continue to do this in future, even if very rarely. Why do you think that giving the engravers a few rubles for their fine work once every three years will spoil them? They have engraved Queens of Spades remarkably quickly and well. ${ }^{79}$

Aware that he himself had been the fortunate recipient of Iurgenson's munificence over the years, Chaikovsky was only too willing to extend such magnanimity to those individuals whose technical skill was indispensable to his relationship both with the musical institutions of Imperial Russia, and with the audience he so assiduously cultivated.

\footnotetext{
${ }^{78}$ Letter of 7/19 July 1890, in ibid., II, 297.

${ }^{79}$ Letter of 10/22 July 1890, in ibid., II, 299.
} 
Chaikovsky's exercise of the powers of patronage was not merely financial; it operated on a symbolic level too. In 1891, he asked Iurgenson to keep an eye on tickets sales for a concert of works by Georgii Konius (Julius Conus), instructing him to buy up 15 or 20 of them anonymously - to support the young composer. ${ }^{80}$ Typically, Iurgenson agreed, whilst disapproving of Chaikovsky's liberality and suggesting that "you can demonstrate your affection merely by showing up on purpose for the concert." ${ }^{\prime 81}$ Chaikovsky's name and persona alone were capable of lending artistic credibility to Konius's reputation, over and above any immediate financial considerations, something that is borne out his continued patronage of Konius's work. On hearing a performance of Konius's orchestral suite, From the Lives of Children, at a concert in Moscow in February 1893, Chaikovsky wrote an enthusiastic letter of support to the Moscow News, which concluded: "May God grant that the composer's great gift should continue to grow and develop, and should encounter from all those charged with dealing and looking after such matters encouragement, support, and sympathy, which are so necessary if a composer is to enjoy success in such an uncommonly thorny field!" 82 Although this letter was not eventually sent, it was discovered amongst Chaikovsky's papers after his death, and as a result, Konius was awarded an annual allowance of 1200 rubles from the Imperial exchequer. Chaikovsky's celebrity was such that he could bestow not just financial support but symbolic capital on other artistic enterprises.

Might this not be one way to reframe his relationship with the Romanov dynasty? Although one cannot downplay the practical significance of the commissions facilitated by the

\footnotetext{
${ }^{80}$ Letter of 22 September/4 October 1891, in ibid., II, 388.

${ }^{81}$ Letter of 25 September/7 October 1891, in ibid., II, 389.

${ }^{82}$ Cited in Chaikovsky, Zhizn' Petra Il'icha Chaikovskogo, III, 535.
} 
Imperial Theaters Directorate, or the usefulness of the state pension granted to him by Alexander III, perhaps the main beneficiary of the relationship was not Chaikovsky, but the autocracy itself. Von Meck's support was disinterested and personal; unknown to all but a handful of the composer's closest friends and supporters, it liberated him from the constraints of teaching and allowed him to concentrate solely on composition. By contrast, his Imperial pension represented less a strategic investment in a career that was, by 1888 , fully established, than a claim on the part of Court to share in the reflected glory of his creativity. The transaction may have worked to Chaikovsky's immediate financial benefit, but the kudos it bought was ultimately meant to reinforce the Romanovs' rule.

\section{Closing balance}

To date, consideration of Chaikovsky's finances has been largely anecdotal, based on incidental references to his need for money in his letters, or metaphorical, where the vocabulary of artistic value is modelled on that of economics. Take for example a letter written to von Meck in September 1880:

I am terribly afraid of becoming a scribbler like, for example, Anton Rubinstein, who seems to consider it his duty for honor the public with new works every day. As a result it turns out that he has broken up his great creative talent for small change and most of his recent works are copper five-ruble coins, and not that pure gold that he could produce, if he wrote at a more measured pace. ${ }^{83}$

${ }^{83}$ Letter of 9-12/21-24 September 1880, in Vaidman (ed.), P. I. Chaikovskii-N. F. fon Mekk: Perepiska, III, 438. 
Yet there is a closer relationship between artistic value and monetary worth than a merely metaphorical one, and an examination of Chaikovsky's correspondence with his publisher, as well as preliminary analysis of his surviving accounts, represent new ways of thinking about Chaikovsky's career in particular, and the operation of musical life in Imperial Russia more generally. Such documents also permit a reevaluation of Iurgenson's central role, whether with respect to Chaikovsky's career, or seen in the context of the professionalization of musical life in Russia in the second half of the nineteenth century. We have underestimated this material not just because certain sources have been unavailable, but also because Chaikovsky's bashfulness has given an impression of his aloofness from the concerns of society. That Chaikovsky was shy is beyond doubt, and he certainly found many of the pressures of his position burdensome. Yet he was profoundly aware of his role within Russian artistic life, as he wrote to Sergei Taneev in August 1880:

I compose, that is, through the language of music, I pour out my moods and feelings, and of course, like anybody who has, or claims to have, something to say, I need people to listen to me. And the more they listen to me, the more congenial this is to me. In this respect, of course I love fame and strive for it with all my soul. [...] However, it does not follow from this that I love the manifestations of fame that take the form of luncheons, suppers and musical soirées, at which I have suffered, as I always suffer in the company of people who are alien to me. If I did enjoy drawing the attention of the public and of society to myself, to my personality, then it would be all too easy to spend my whole life at all kinds of social gatherings. But surely you must know that I have never aspired to 
this, and that, on the contrary, I always strive to bury myself somewhere where I can exist outside of society. I want, desire and love that people take an interest in my music, that they praise and love it, but I have never sought to encourage them to take an interest in me personally, in my appearance or my conversation. ${ }^{84}$

Even as he shrunk from the public manifestations of his fame, Chaikovsky became an active figure in the "art world" of late imperial Russian music. Moreover, he did not merely respond to a series of economic and institutional developments, but, in concert with Iurgenson, interacted consciously and constructively with such developments, leaving behind him both a legacy of musical compositions that continue to form the core of the Russian repertoire, and a clearer sense of the kind of roles that might be inhabited by the modern, professional musician.

${ }^{84}$ Letter of 1/13 August 1880, in Chaikovskii, Polnoe sobranie sochinenii, X (1965), 222 